\title{
Bruk av psykofarmaka må følges opp tverrfaglig og systematisk
}

Pasienter med psykiske lidelser har ofte et stort forbruk av legemidler, noe som kan føre til både bivirkninger og terapisvikt.

Psykisk helse

Legemidler

Sykepleien 2021109 (86136) (e-86136)

DOI: 10.4220/Sykepleiens.2021.86136

\section{Hovedbudskap}

Pasienter med psykiske lidelser behandles ofte med legemiddelkombinasjoner som ikke er dokumentert, i doser som ikke er anbefalt, og på ikke-godkjent indikasjon. Terapisvikt og bivirkninger er vanlig. God legemiddelbehandling inkluderer tverrfaglig oppfølging, med rapportering av virkninger og bivirkninger. I denne artikkelen presenterer vi ti spørsmål som kan være til hjelp i oppfølgingen av pasienter som bruker psykofarmaka. 